\title{
Epidemiology and economic burden of measles, mumps, pertussis, and varicella in Germany: a systematic review
}

\author{
Oliver Damm • Julian Witte $\cdot$ Stefanie Wetzka $\cdot$ Christine Prosser • \\ Sebastian Braun $\cdot$ Robert Welte $\cdot$ Wolfgang Greiner
}

Received: 23 December 2015/Revised: 21 April 2016/Accepted: 2 June 2016/Published online: 4 August 2016

(C) The Author(s) 2016. This article is published with open access at Springerlink.com

\begin{abstract}
Objectives Despite the availability of vaccines and the existence of public vaccination recommendations, outbreaks of vaccine-preventable childhood diseases still cause public health debate. The objective of this systematic review was to provide an overview of the current epidemiology and economic burden of measles, mumps, pertussis, and varicella in Germany.

Methods We systematically reviewed studies published since 2000. The literature search was conducted using PubMed and EMBASE. Also, we used German notification data to give an up-to-date overview of the epidemiology of the four diseases under consideration.

Results Thirty-six studies were included in our review. Results suggest that there is still considerable morbidity due to childhood diseases in Germany. Studies providing cost estimates are scarce. Comparative analyses of different data sources (notification data vs. claims data) revealed a potential underestimation of incidence estimates when using notification data. Furthermore, several studies
\end{abstract}

Electronic supplementary material The online version of this article (doi:10.1007/s00038-016-0842-8) contains supplementary material, which is available to authorized users.

O. Damm $(\bowtie) \cdot$ J. Witte · W. Greiner

Department of Health Economics and Health Care Management, School of Public Health, Bielefeld University, Universitätsstraße 25, 33615 Bielefeld, Germany

e-mail: oliver.damm@uni-bielefeld.de

S. Wetzka $\cdot$ R. Welte

GlaxoSmithKline Germany, Prinzregentenplatz 9, 81675

Munich, Germany

C. Prosser $\cdot$ S. Braun

Xcenda GmbH, Lange Laube 31, 30159 Hanover, Germany showed regional differences in incidence of some of the diseases under consideration.

Conclusions Our findings underline the need for improved vaccination and communication strategies targeting all susceptible age and risk groups on a national and local level.

Keywords Childhood diseases · Epidemiology ·

Economic burden · Germany

\section{Introduction}

Vaccination is regarded as one of the great public health achievements (CDC 1999) and has led to substantial decreases in morbidity and mortality of vaccine-preventable diseases (Roush and Murphy 2007). However, despite the availability of vaccines and the existence of public vaccination recommendations, vaccine-preventable childhood diseases are still a subject of public health debate and research. This is mostly due to outbreaks such as the large measles outbreak in Berlin in 2014/2015 (RKI 2015b).

In Germany, current vaccination recommendations of the Standing Vaccination Committee (STIKO) cover, among others, routine childhood vaccination against measles, mumps, pertussis, and varicella (Table 1). Some of these recommendations have existed for decades and undergone several updates. A detailed description of the history of vaccination recommendations in Germany was published by Klein et al. (2012).

In many countries, the introduction of vaccination recommendations is accompanied by the implementation of infectious disease surveillance systems. The primary aim of such surveillance systems is to collect and analyse 


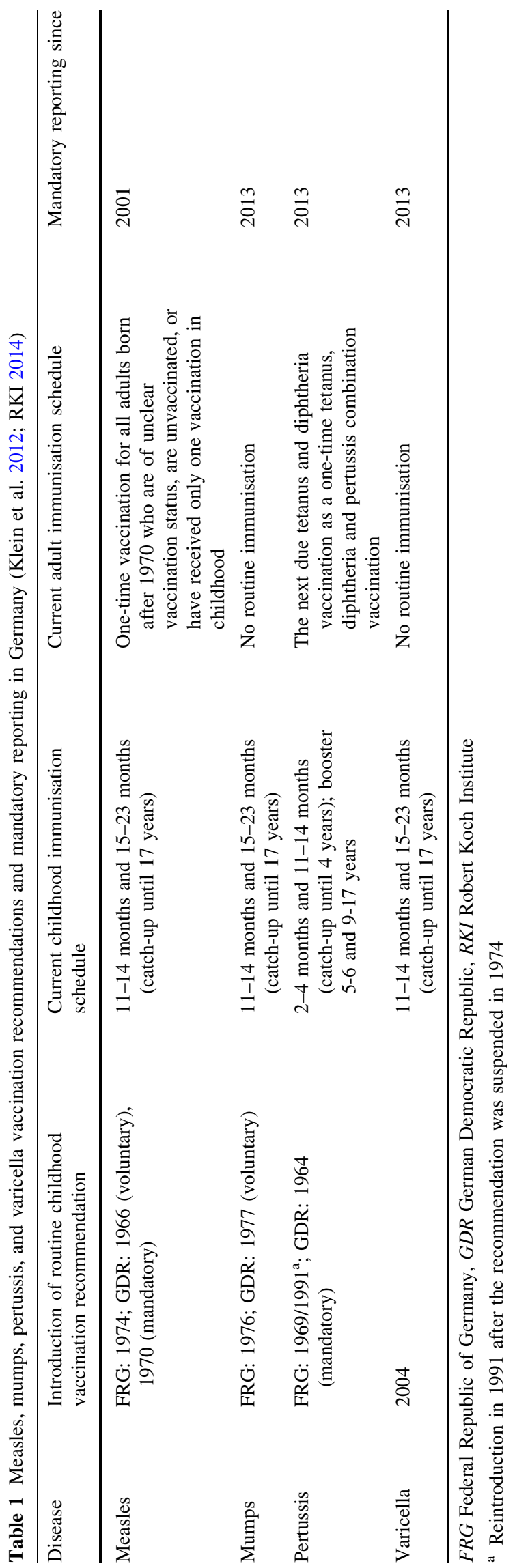

infectious disease data on an ongoing basis. These data can be used to detect outbreaks and to evaluate the impact of interventions. Surveillance data can be collected through various methods including passive surveillance, active surveillance, and sentinel surveillance (Declich and Carter 1994; MacDonald 2012; Oleckno 2008; Roush 2011):

- Passive surveillance mainly refers to national notification systems based on mandatory case reporting. This means that health care providers (e.g. physicians and hospitals) and laboratories are required by law to routinely report the occurrence of certain infectious diseases to public health officials. Passive surveillance is the most common method for collecting data on vaccine-preventable diseases. It captures the entire population and requires relatively few resources, but completeness of reporting is highly dependent on the compliance of health facilities. Moreover, diagnostic accuracy can differ among health care providers, particularly since case definition criteria of notification systems often include not only laboratory-confirmed cases but also clinically diagnosed cases.

- Active surveillance involves a proactive search for cases by health authorities through contacting health care providers on a regular basis. This data collection procedure can provide a more complete picture of disease frequency, but it is usually more costly than passive surveillance. That is why active surveillance is often limited to outbreaks or other short-term investigations.

- Sentinel surveillance, which may comprise elements of both active and passive surveillance approaches, relies on a limited number of carefully selected reporting sites. Selection criteria may include representativeness, geographic area, and practical considerations related to feasibility and reporting quality (e.g. willingness to participate, well-qualified staff, and adequate technical resources). Sentinel surveillance requires fewer resources than population-based surveillance and can provide high-quality data. The main shortcoming of this approach is that the generalisability of the findings may be limited.

Further data collection procedures include surveillance surveys, epidemic field investigations and the use of secondary data sets (Declich and Carter 1994). In Germany, measles has been a notifiable disease since 2001. Mumps, pertussis, and varicella became notifiable on a national level in March 2013 (Table 1). German sentinel systems were, among others, developed for the surveillance of measles (Siedler and Leitmeyer 2004) and varicella (Siedler and Arndt 2010).

In 2010, the 53 member states of the World Health Organization (WHO) European Region renewed their 
commitment to the elimination of measles by 2015 (WHO 2010). Nevertheless, the outbreak in Berlin in 2014/2015 (RKI 2015b) clearly demonstrates that Germany has not met the elimination target so far. Therefore, the objective of this study is to systematically review the existing literature on the current epidemiology and economic burden of measles and other childhood diseases (namely mumps, pertussis, and varicella) in Germany.

Epidemiological measures of interest include incidence, frequency of complications and long-term sequelae, mortality, outbreak descriptions, and disabilityadjusted life years (DALYs). The DALY is a summary measure of population health that captures the burden of morbidity and mortality in a single metric. DALYs for a particular disease are calculated as the sum of the time lost due to premature death and the time lived with poor health or disability. The concept includes weighting of disease duration with a weight factor that reflects the severity of the health condition (Murray 1994). Since the development of this measure in the early 1990s, the methods used to calculate DALYs have undergone several changes (Devleesschauwer et al. 2014; Murray et al. 2012; Voigt and King 2014). The DALY approach is primarily used by the WHO to quantify the global burden of disease.

Our definition of economic burden covers resource consumption (particularly hospitalisation), illness-related work days lost, and direct and indirect costs. Direct costs primarily capture the cost of medical care (e.g. drug therapy, physician consultations, inpatient treatment), whereas indirect costs mainly refer to productivity losses due to absence from work and premature death.

\section{Methods}

\section{Literature search}

We searched in the literature databases PubMed and EMBASE for relevant papers published between 1 January 2000 and 8 February 2015. Search terms included controlled vocabulary and free-text terms. Details of the search strategy are provided in the supplementary material (Online Resource 1). Two investigators (OD and JW) independently screened search results and assessed the eligibility of potentially relevant studies according to predefined inclusion and exclusion criteria. Discrepancies were solved through discussion involving a third investigator (SW). Reference lists of identified studies were searched manually for further relevant publications. We followed the PRISMA guidelines for conducting and reporting systematic reviews (Moher et al. 2009).
Inclusion and exclusion criteria

We included English and German language articles reporting data on the epidemiology and economic burden of measles, mumps, pertussis, and varicella in Germany. We did not apply restrictions concerning the type of study and the method of data collection. We wanted to focus as far as possible on the general population and, therefore, excluded studies restricted to health care workers, military personnel and their families. We also excluded pure review articles, comments, letters, editorials, single case-reports, small case series and outbreak reports with fewer than 10 subjects, articles without full-text (e.g. conference abstracts), and surveillance and outbreak reports lacking a separate methods section.

\section{Data extraction}

Data extraction was performed by one investigator (OD) and verified by a second (JW). The following data were abstracted from the included studies: type of study, data sources and methods, population and setting, time frame, outcome measures, and results.

\section{Surveillance data}

In addition to our literature search, we used notification data of the German Protection against Infection Act (Infektionsschutzgesetz) to give an up-to-date overview on the epidemiology of measles, mumps, pertussis, and varicella in Germany. The numbers of notified cases were extracted using a web-based data query tool (SurvStat@RKI 2.0).

\section{Results}

Literature review

After duplicates were removed, the bibliographic search using PubMed and EMBASE databases yielded 1700 records. After screening of titles and abstracts, 1568 records were excluded and 132 full-text articles were subsequently assessed for eligibility. Ninety-six articles were excluded after full-text assessment. Main reasons for exclusion were study objective (e.g. vaccination coverage or vaccine effectiveness), publication type (e.g. review article, case report, or comment), or lack of a sufficient methods section. Thirty-six studies fulfilled the inclusion criteria and were, therefore, included in this review. Figure 1 shows the process of study identification and selection.

Of the 36 included studies, 18 reported results for measles, two for mumps, six for pertussis, and ten for varicella. Most of the studies were mainly based on data 


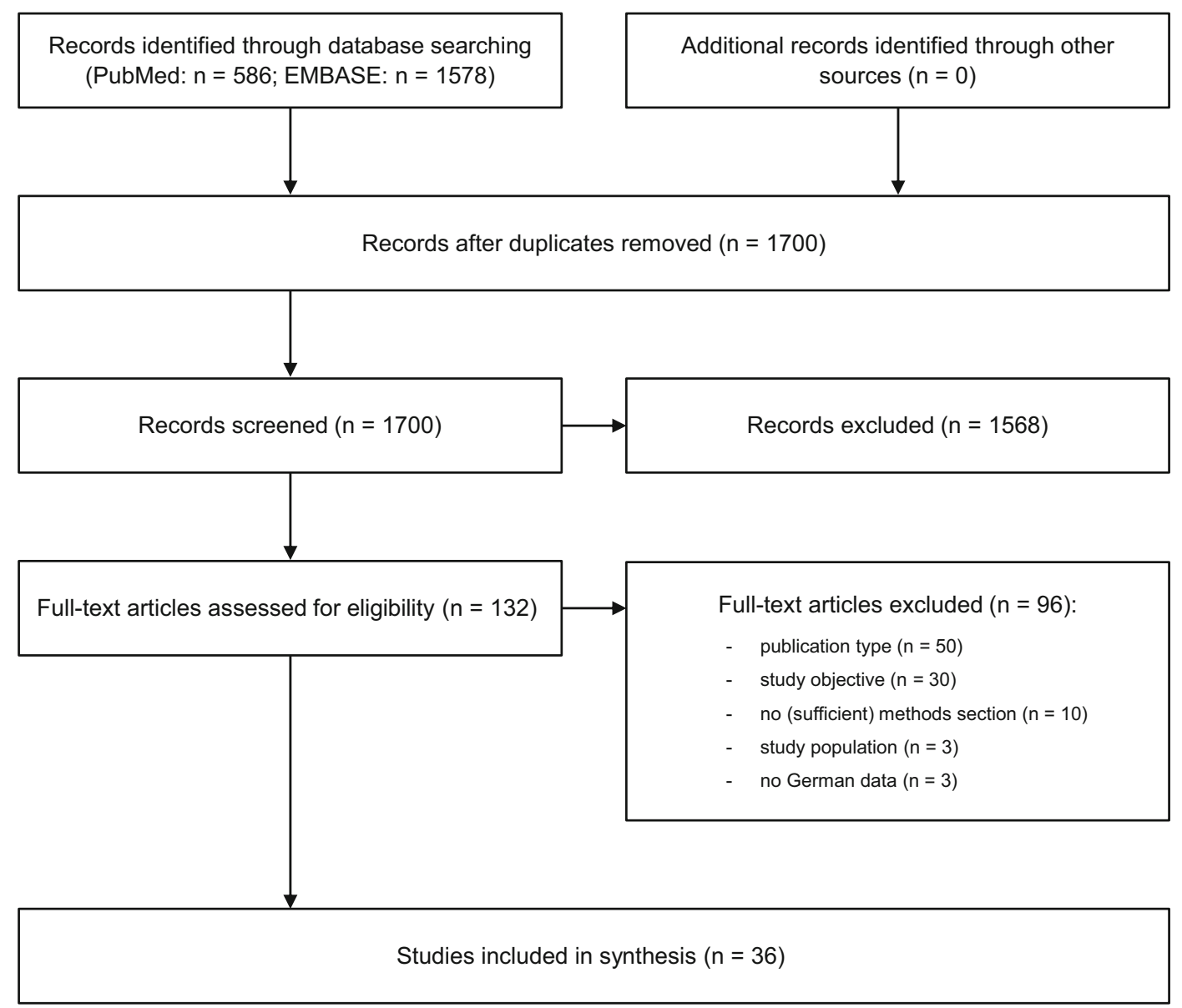

Fig. 1 Flowchart of the study identification and selection process

from (mandatory) notification and/or sentinel surveillance systems. Four of these studies used data from a paediatric hospital-based surveillance system, called ESPED (Erhebungseinheit für seltene pädiatrische Erkrankungen in Deutschland; German paediatric surveillance unit). Three studies used claims data of the Associations of Statutory Health Insurance Physicians (ASHIP). Two studies explicitly applied (decision-analytic) modelling approaches. Other methods and data sources used include survey and interview methods, contact tracing activities, and review of medical files or national statistics. The majority of the included studies $(n=34)$ provided data on epidemiological outcomes and/or hospitalisation. Only few studies reported on economic aspects in terms of costs and/ or work days lost $(n=5)$. Table 2 summarises the characteristics and results of the included studies. The main results are also described in the following paragraphs.

\section{Measles}

Incidence estimates based on analyses of surveillance data ranged widely across studies and years (from $<0.1$ to 38.9 per 100,000 inhabitants per year). Outbreak-related incidence estimates ranged between 12 and 32 per 100,000 inhabitants. One study examining the epidemiology of measles from 2007 to 2011 (Takla et al. 2014) showed large geographical differences in incidence of measles with the highest incidence in southern Germany. Another study presenting results for 1999 to 2001 (Tischer et al. 2002) found that most cases of measles occurred in southern Germany and in North Rhine-Westphalia. Two studies (Mette et al. 2011; Takla et al. 2014) compared results of the analyses of surveillance data and ASHIP claims data and found that incidence estimates based on ASHIP data were higher than estimates based on notification data. Some studies only reported absolute numbers of cases instead of presenting data as incidence rates (see Table 2 for details). The proportion of patients developing any complications varied from 15 to $24 \%$. The most frequent complications of measles were otitis media and pneumonia. In hospitalised children, pneumonia was diagnosed in more than $50 \%$ of the patients (Arenz et al. 2009). The proportion of measles-associated hospitalisations ranged from 2.2 to $40 \%$ in studies examining all ages. One study found a proportion of 
Table 2 Study characteristics and results

\begin{tabular}{|c|c|c|c|}
\hline Publication & $\begin{array}{l}\text { Methods (study type, data source, } \\
\text { population, and time frame) }\end{array}$ & Outcome measures & Results \\
\hline \multicolumn{4}{|l|}{ Measles } \\
\hline \multirow{4}{*}{$\begin{array}{l}\text { Arenz et al. } \\
(2009)\end{array}$} & \multirow{4}{*}{$\begin{array}{l}\text { Analysis of surveillance data; paediatric } \\
\text { hospital-based surveillance data (ESPED); } \\
\text { hospitalised children and } \\
\text { adolescents }<16 \text { years (detailed } \\
\text { questionnaire-based information was } \\
\text { obtained for } 96 \text { children); } 2006\end{array}$} & Children hospitalised for measles & 115 children ( $42 \%$ were $<2$ years $)$ \\
\hline & & Median length of hospital stay & 6 days \\
\hline & & Complications & $\begin{array}{l}\text { Pneumonia: } 54 \% \text {; otitis media: } 11 \% \text {; seizures: } \\
\quad 7 \%\end{array}$ \\
\hline & & Measles-related deaths & 2 children died of measles (with encephalitis) \\
\hline $\begin{array}{l}\text { Carabin } \\
\text { et al. (2003) }\end{array}$ & $\begin{array}{l}\text { Multi-country cost study; country-specific } \\
\text { incidence and cost data; direct costs include } \\
\text { physicians' visits, prescription medication, } \\
\text { hospitalisation, and long-term care for }\end{array}$ & $\begin{array}{l}\text { Average annual costs ( } 2001 \text { values) of } \\
\text { caring for measles per capita in } \\
\text { Germany from a health care } \\
\text { provider perspective }\end{array}$ & Approximately EUR 0.02 per capita \\
\hline
\end{tabular}

Gillesberg Outbreak report; notification data and clinical Lassen data collected through interviews with caseet al. (2014) patients; community members, students of an anthroposophic school, and family members and friends of the students in Berlin; AprilJuly 2011

Hegasy et al. Outbreak report; notification data and contact (2012) tracing activities; non-Roma inhabitants and Roma community members living in Hamburg; December 2008-June 2009

Mankertz Study on spread of the D4-Hamburg strain; et al. (2011) results of laboratory samples; general population in Germany; 2008-2010

Mette et al. Claims data analysis and comparison with (2011) surveillance data; ASHIP billing data and notification data; 15.4 million people covered by statutory health insurance living in North Rhine-Westphalia; 2006-2007

Muscat et al. Multi-country analysis of surveillance data; (2009) data of national mandatory notification systems; general population in Germany; 2006-2007

Muscat et al. Multi-country analysis of surveillance data; (2014) data submitted by national surveillance institutions to the WHO Regional Office for Europe; general population in Germany; 2012-2013

Plass et al. Burden of disease study; DALY estimates are (2014) based on a model of the natural history of disease using notification data; general population in Germany; 2005-2007

Roggendorf Outbreak report; surveillance data of a et al. (2012) community health centre; 1st outbreak: children attending a free progressive school in Essen and their contacts; 2nd outbreak: children and adults in a low socio-economic setting and with migration background in Essen; March-July 2010

Siedler et al. Outbreak report; surveillance data of the (2006) mandatory reporting system and data collected through interviews of the local health authorities with physicians and family members; general population in Hesse and Bavaria; January-May 2005 (Hesse) and March-July 2005 (Bavaria)
Cases of measles

Hospitalisation

Cases of measles

Cases of measles

Hospitalisation

Confirmed measles diagnoses (ASHIP data)

Reported cases of measles (notification data)

Ratio of confirmed measles diagnoses and reported cases of measles

Cases of measles

Incidence per 100,000 inhabitants

Measles-related deaths

Cases of measles

Incidence per million inhabitants per year

Average loss of DALYs per year

Average loss of DALYs per case

Cases of measles

Hospitalisation

73 cases $(27 \%$ of all case-patients and $38 \%$ of community case-patients were $\geq 20$ years)

$15 \%$

216 cases (69\% were confirmed by laboratory analyses); a local Roma community comprised more than $50 \%$ of the notified cases

216 cases in Hamburg; 72 cases in Lower Saxony; 48 cases in Munich; several cases occurred in Roma community members and asylum seekers

$40 \%$ of patients (due to pneumonia or otitis media)

2534 diagnoses $(87 \%$ of billed measles diagnoses occurred in children $<10$ years)

2014 cases ( $40 \%$ of measles cases were reported for children $<10$ years)

1.26: 1 (underreporting)

2307 cases in 2006; 571 cases in 2007

2.8 per 100,000 in 2006 ; 0.7 per 100,000 in 2007

2 fatal cases in children (caused by encephalitis)

167 cases in $2012 ; 1773$ cases in 2013

2 per million in 2012; 21.4 per million in 2013

740 DALYs (93\% was due to acute symptomatic infections and $7 \%$ was due to long-term sequelae)

0.26 DALYs

1st outbreak: 75 cases; 2nd outbreak: 11 cases $15 \%$
Cases of measles (without sporadic cases)

Incidence per 100,000 inhabitants

Hospitalisation in patients $\geq 20$ years

Measles-related deaths
Hesse: 223 cases; Bavaria: 279 cases; $74 \%$ in school aged children

Hesse: 14 per 100,000; Bavaria: 12 per 100,000

Outbreak in Hesse: $34 \%$

Outbreak in Hesse: 1 case 
Table 2 continued

\begin{tabular}{|c|c|c|c|}
\hline Publication & $\begin{array}{l}\text { Methods (study type, data source, } \\
\text { population, and time frame) }\end{array}$ & Outcome measures & Results \\
\hline \multirow{2}{*}{$\begin{array}{l}\text { Siedler et al. } \\
(2013 a)\end{array}$} & \multirow{2}{*}{$\begin{array}{l}\text { Analysis of surveillance data; sentinel data } \\
\text { collected by } 1488 \text { paediatric and primary } \\
\text { care practices; patients of practices } \\
\text { participating in the sentinel system; } \\
2001-2010\end{array}$} & Cases of measles & 3100 cases ( 2495 cases in children $<10$ years) \\
\hline & & Complications & $15 \%$ (mostly otitis media and pneumonia) \\
\hline \multirow{3}{*}{$\begin{array}{l}\text { Takla et al. } \\
\text { (2014) }\end{array}$} & \multirow{3}{*}{$\begin{array}{l}\text { Claims data analysis and comparison with } \\
\text { surveillance data; ASHIP billing data and } \\
\text { mandatory notification data; } 68 \% \text { (2007) } \\
\text { and } 79 \% \text { (2008-2011) of the total } \\
\text { population living in Germany (ASHIP data); } \\
\text { 2007-2011 }\end{array}$} & Cases of measles (notification data) & 4440 cases \\
\hline & & $\begin{array}{l}\text { Annual incidence per million } \\
\text { population (notification data) }\end{array}$ & $\begin{array}{l}\text { Total: } 10.8 \text { per million (range } 6.9-19.6 \text { per } \\
\text { year); northern Germany: } 8.7 \text {; western } \\
\text { Germany: } 7.2 \text {; eastern Germany: } 5.5 ; \\
\text { southern Germany: } 20.3\end{array}$ \\
\hline & & $\begin{array}{l}\text { Annual incidence per million residents } \\
\text { with statutory health insurance } \\
\text { (ASHIP data) }\end{array}$ & $\begin{array}{l}27.5 \text { per million; incidence based on ASHIP } \\
\text { data was up to } 4.8 \text {-fold higher than incidence } \\
\text { based on notified cases }\end{array}$ \\
\hline \multirow{4}{*}{$\begin{array}{l}\text { Tischer et al. } \\
(2001)\end{array}$} & \multirow{4}{*}{$\begin{array}{l}\text { Analysis of surveillance data; sentinel data and } \\
\text { notification data; general population in } \\
\text { Germany; October 1999-March } 2001\end{array}$} & Cases of measles (sentinel data) & 1291 cases \\
\hline & & Complications (sentinel data) & $24 \%$ \\
\hline & & Hospitalisation (sentinel data) & $2.2 \%$ \\
\hline & & Incidence per 100,000 inhabitants & $\begin{array}{l}38.9 \text { per } 100,000 \text { (sentinel data); }<0.5-5.7 \text { per } \\
100,000 \text { (notification data of the first quarter } \\
\text { of } 2001 \text { ) }\end{array}$ \\
\hline \multirow{4}{*}{$\begin{array}{l}\text { Tischer et al. } \\
\text { (2002) }\end{array}$} & \multirow{4}{*}{$\begin{array}{l}\text { Analysis of surveillance data; sentinel data } \\
\text { collected by } 1271 \text { paediatric and primary } \\
\text { care practices; general population in } \\
\text { Germany; October } 1999-\text { September } 2001\end{array}$} & Cases of measles & 1720 cases \\
\hline & & Incidence per 100,000 inhabitants & $\begin{array}{l}20 \text { per } 100,000 \text { (range }<1-56 \text { per } 100,000, \\
\text { depending on the federal state) }\end{array}$ \\
\hline & & Complications & $16 \%$ (mostly otitis media and pneumonia) \\
\hline & & Hospitalisation & $2.4 \%$ \\
\hline \multirow{4}{*}{$\begin{array}{l}\text { Wadl et al. } \\
(2011)\end{array}$} & \multirow{4}{*}{$\begin{array}{l}\text { Outbreak report; surveillance data and data } \\
\text { collected through questionnaires; general } \\
\text { population in four Bavarian counties } \\
\text { (including attendees of an anthroposophic } \\
\text { school in Austria); March-July } 2008\end{array}$} & Cases of measles & 217 cases \\
\hline & & Incidence per 100,000 population & 32 per 100,000 \\
\hline & & Hospitalisation & $11 \%$ \\
\hline & & Complications & $18 \%$ \\
\hline \multirow{3}{*}{$\begin{array}{l}\text { Wichmann } \\
\text { et al. (2007) }\end{array}$} & \multirow{3}{*}{$\begin{array}{l}\text { Retrospective cohort study on the initial phase } \\
\text { of an outbreak; data collected through } \\
\text { questionnaires; } 1098 \text { students aged } \\
\text { 10-21 years of a public day school in } \\
\text { Duisburg; January-May } 2006\end{array}$} & Cases of measles & 53 cases \\
\hline & & Hospitalisation & $4 \%$ \\
\hline & & Complications & $\begin{array}{l}\text { Otitis media: } 4 \text { cases; pneumonia: } 1 \text { case; } \\
\text { encephalitis: } 1 \text { case }\end{array}$ \\
\hline \multirow{8}{*}{$\begin{array}{l}\text { Wichmann } \\
\text { et al. (2009) }\end{array}$} & \multirow{8}{*}{$\begin{array}{l}\text { Study on outbreak-related morbidity and costs; } \\
\text { surveillance data and data collected through } \\
\text { questionnaires/interviews (face-to-face or by } \\
\text { telephone); health care provider costs } \\
\text { (including physician consultations, } \\
\text { laboratory tests, antibiotic treatment, and } \\
\text { hospitalisation) are calculated using DRGs, } \\
\text { the outpatient fee schedule and medication } \\
\text { prices; general population in Duisburg; } 2006\end{array}$} & Cases of measles & 614 cases in Duisburg \\
\hline & & Hospitalisation & $15 \%$ \\
\hline & & Antibiotic treatment & $32 \%$ \\
\hline & & Complications & $\begin{array}{l}\text { Otitis media: } 19 \% \text {; pneumonia: } 7 \% \text {; } \\
\text { encephalitis: } 0.6 \%\end{array}$ \\
\hline & & Measles-related deaths & $\begin{array}{l}2 \text { fatal cases in children (caused by } \\
\text { encephalitis) }\end{array}$ \\
\hline & & School days missed & 2854 days \\
\hline & & Work days lost & 301 days \\
\hline & & Average costs (2006 values) & $\begin{array}{l}\text { EUR } 373 \text { per measles patient; EUR } 1877 \text { per } \\
\text { hospitalised patient }\end{array}$ \\
\hline \multicolumn{4}{|l|}{ Mumps } \\
\hline \multirow[t]{2}{*}{$\begin{array}{l}\text { Otto et al. } \\
(2010)\end{array}$} & \multirow[t]{2}{*}{$\begin{array}{l}\text { Outbreak report; laboratory samples and } \\
\text { clinical data; adolescents and young adults in } \\
\text { Bavaria; July-October } 2010\end{array}$} & Laboratory-confirmed infections & $\begin{array}{l}115 \text { laboratory-confirmed mumps infections } \\
\text { (median age: } 24.5 \text { years, predominantly male } \\
\text { patients) }\end{array}$ \\
\hline & & Complications & 1 case of meningitis and 21 cases of orchitis \\
\hline
\end{tabular}


Table 2 continued

\begin{tabular}{|c|c|c|c|}
\hline Publication & $\begin{array}{l}\text { Methods (study type, data source, } \\
\text { population, and time frame) }\end{array}$ & Outcome measures & Results \\
\hline \multirow[t]{2}{*}{$\begin{array}{l}\text { Takla et al. } \\
\text { (2013) }\end{array}$} & $\begin{array}{l}\text { Claims data analysis and comparison with } \\
\text { surveillance data; ASHIP billing data and } \\
\text { notification data; statutory health-insured } \\
\text { population and general population in the } \\
\text { eastern and western federal states of } \\
\text { Germany; 2007-2011 }\end{array}$ & $\begin{array}{l}\text { Countrywide mean annual incidence } \\
\text { per } 100,000 \text { people covered by } \\
\text { statutory health insurance }\end{array}$ & $\begin{array}{l}10.3 \text { per } 100,000 \text { (range } 9.3-11.8 \text { ); incidence } \\
\text { was significantly higher in western than in } \\
\text { eastern federal states; comparison of } \\
\text { notification data with ASHIP data indicated } \\
\text { severe underreporting of incidence estimates } \\
\text { based on notification data }\end{array}$ \\
\hline & & Complications & $\begin{array}{l}\text { Orchitis: } 6.2 \% \text { of male cases; meningitis: } \\
0.4 \% ; \text { pancreatitis: } 0.3 \% \text {; encephalitis: } \\
0.2 \% \text {; proportion of complications in } \\
\text { cases } \geq 15 \text { years was significantly higher } \\
\text { than in cases }<15 \text { years }\end{array}$ \\
\hline
\end{tabular}

Pertussis

Hellenbrand Analysis of surveillance data; surveillance data et al. (2009) (notification and sentinel data) and hospital discharge statistics; general population in Germany; 2000-2007

Juretzko Analysis of surveillance data; paediatric et al. (2001) hospital-based surveillance data (ESPED) and clinical data collected through questionnaires; children $<16$ years; 1997-1998

Liese et al. Prospective long-term surveillance study; (2003) follow-up data of a population-based casecontrol efficacy study; 11,087 children (3-8 years) of the original study population and all other children of the same age group presenting in the participating paediatric practices; $8.3 \%$ were not vaccinated against pertussis; May 1997-March 1999

Riffelmann Prospective incidence and cost study; et al. (2006) laboratory samples, clinical and resource consumption data collected through questionnaires; direct costs include physician consultations, laboratory tests, and medication; indirect costs are based on the number of work days lost and a cost of EUR 114.30 per day; 971 primary care patients having cough for $\geq 7$ days in two German cities (Krefeld and Rostock); economic analysis is based on 45 cases of pertussis; 2001-2004

Sin et al

Outbreak report; active case finding by the local health authorities and a retrospective cohort study performed in 4 affected schools (questionnaires); mostly children and adolescents attending schools in Ludwigslust district, Mecklenburg-Western Pomerania; 2005-2006
Incidence per 100,000 inhabitants in eastern federal states (notification data)

Incidence in adults per 100,000 inhabitants

Hospitalisation in eastern federal states (surveillance data)

Hospitalisation (cases per 100,000 population, hospital discharge statistics)

Standardised incidence of pertussis requiring hospitalisation per 100,000 person-years

Mean length of hospital stay

Complications in hospitalised children

Pertussis-related deaths in hospitalised $0.3 \%$ children

Cases of pertussis

Incidence per 1000 person-years

Proportion of patients with pertussis

Incidence per 100,000 inhabitants

Pertussis patients with antibiotic prescription

Average direct costs (2004 values) per EUR 120 case

Average indirect costs (2004 values) EUR 2443 per case in employed patients 2007

14.9 days

$10 \%$

$53 \%$
20.5 per 100,000 in $2000 ; 39.3$ per 100,000 in

$160-169$ per 100,000 in $2002-2004$

$1.9-4.9 \%$ in $2002-2007$ (depending on the federal state)

1.7 per 100,000 in eastern federal states in $2007 ; 1.5$ per 100,000 in western federal states in 2005; most cases occurred in children $<1$ year

2.70 per 100,$000 ; 2.36$ per 100,000 in western federal states; 4.50 per 100,000 in eastern federal states

All: $44 \%$ (60\% occurred in children $<6$ months); pneumonia: $28.1 \%$; apnea: $20.6 \%$; seizures: $2.5 \%$; encephalopathy: $2.1 \%$

180 cases; $64 \%$ were caused by $B$ pertussis infections and $36 \%$ were caused by $B$ parapertussis infections

$B$ pertussis infections: 4.8 per $1000 ; B$ parapertussis infections: 2.8 per 1000

165 per 100,000

104 cases

$1.9-32.0 \%$ (depending on the time since last vaccine dose); results suggest that vaccineinduced immunity begins to wane approximately 5 years after completion of the primary series 
Table 2 continued

\begin{tabular}{|c|c|c|c|}
\hline Publication & $\begin{array}{l}\text { Methods (study type, data source, } \\
\text { population, and time frame) }\end{array}$ & Outcome measures & Results \\
\hline \multirow{4}{*}{$\begin{array}{l}\text { Stojanov } \\
\text { et al. (2000) }\end{array}$} & \multirow{4}{*}{$\begin{array}{l}\text { Prospective surveillance study; data of a case- } \\
\text { control efficacy study; } 11,016 \\
\text { children }<2 \text { years presenting with } \\
\text { cough } \leq 7 \text { days at } 63 \text { paediatric practices in } \\
\text { Germany; March } 1993 \text {-May } 1995\end{array}$} & Proportion of patients with pertussis & $6.6 \%$ \\
\hline & & Hospitalisation & $4.5 \%$ \\
\hline & & $\begin{array}{l}\text { Complications in hospitalised } \\
\text { pertussis patients }\end{array}$ & $\begin{array}{l}\text { All: } 48 \% \text {; bradycardia: } 21 \% \text {; apnea: } 12 \% \text {; } \\
\text { conjunctivitis: } 12 \% \text {; pneumonia: } 6 \% \text {; otitis } \\
\text { media: } 6 \%\end{array}$ \\
\hline & & Mean length of hospital stay & 8 days \\
\hline \multicolumn{4}{|l|}{ Varicella } \\
\hline \multirow[t]{2}{*}{$\begin{array}{l}\text { Banz et al. } \\
(2004)\end{array}$} & \multirow{2}{*}{$\begin{array}{l}\text { Cost study; cost estimates are based on a } \\
\text { decision-analytic model using survey data } \\
\text { (Wagenpfeil et al. 2004); direct costs include } \\
\text { physician consultations, medication, and } \\
\text { hospitalisation; transfer payments are based } \\
\text { on parental work days lost; indirect costs are } \\
\text { based on the number of work days lost and a } \\
\text { cost of EUR } 150 \text { per day; general population } \\
\text { in Germany; } 1999 \text { prices (pre-vaccination } \\
\text { era) }\end{array}$} & $\begin{array}{l}\text { Annual third-party payer costs (1999 } \\
\text { values of direct costs and transfer } \\
\text { payments to parents caring for their } \\
\text { sick children) }\end{array}$ & EUR 78 million (direct medical costs: $43 \%$ ) \\
\hline & & $\begin{array}{l}\text { Annual societal costs (1999 values of } \\
\text { direct and indirect costs) }\end{array}$ & EUR 187.5 million (direct medical costs: $18 \%$ ) \\
\hline \multirow[t]{2}{*}{$\begin{array}{l}\text { Grote et al. } \\
(2007)\end{array}$} & \multirow{2}{*}{$\begin{array}{l}\text { Analysis of surveillance data; paediatric } \\
\text { hospital-based surveillance data (ESPED); } \\
\text { paediatric population up to the age of } \\
17 \text { years; 2003-2004 (pre-vaccination era) }\end{array}$} & Cases of varicella-associated deaths & $\begin{array}{l}10 \text { cases (none was vaccinated against } \\
\text { varicella) }\end{array}$ \\
\hline & & $\begin{array}{l}\text { Annual mortality rate (cases per } \\
\text { million children) }\end{array}$ & 0.4 per million \\
\hline \multirow[t]{5}{*}{$\begin{array}{l}\text { Liese et al. } \\
(2008)\end{array}$} & \multirow{5}{*}{$\begin{array}{l}\text { Analysis of surveillance data; nationwide } \\
\text { paediatric hospital-based surveillance data } \\
\text { (ESPED), practice sentinel network and } \\
\text { hospital diagnosis data in one federal state } \\
\text { (North Rhine-Westphalia); } \\
\text { children } \leq 16 \text { years; 2003-2004 (pre- } \\
\text { vaccination era) }\end{array}$} & $\begin{array}{l}\text { Hospitalised varicella cases (ESPED } \\
\text { data) }\end{array}$ & 918 cases (with a median age of 3.3 years) \\
\hline & & $\begin{array}{l}\text { Annual incidence of varicella-related } \\
\text { hospitalisations (cases per 100,000 } \\
\text { children) }\end{array}$ & $\begin{array}{l}3.25 \text { per } 100,000 \text { (ESPED data); } 14.1 \text { per } \\
100,000 \text { (capture-recapture methodology for } \\
\text { two sources); } 19.7 \text { per } 100,000 \text { (hospital } \\
\text { diagnosis data) }\end{array}$ \\
\hline & & Median length of hospital stay & 5 days \\
\hline & & Complications in hospitalised cases & $\begin{array}{l}\text { All: } 79.6 \% \text {; neurological: } 25.4 \% \text {; skin: } \\
\text { 23.2\%; gastrointestinal tract: } 15 \% \text {; lower } \\
\text { respiratory tract: } 11.8 \% \text {; severe systemic } \\
\text { bacterial infections: } 4.4 \%\end{array}$ \\
\hline & & Cases of varicella-associated deaths & 10 cases \\
\hline $\begin{array}{l}\text { Siedler and } \\
\text { Arndt } \\
(2010)\end{array}$ & $\begin{array}{l}\text { Analysis of surveillance data; sentinel data } \\
\text { collected by paediatricians and general } \\
\text { practitioners; general population in } \\
\text { Germany; April 2005-March } 2009 \\
\text { (vaccination era) }\end{array}$ & Cases of varicella and trend analysis & $\begin{array}{l}83,181 \text { cases; sentinel data showed a reduction } \\
\text { of } 55 \% \text { of varicella cases in all ages over } \\
\text { time }\end{array}$ \\
\hline $\begin{array}{l}\text { Siedler et al. } \\
(2013 b)\end{array}$ & $\begin{array}{l}\text { Analysis of surveillance data; sentinel data, } \\
\text { notification data, and hospital diagnosis } \\
\text { statistics; general population in Germany; } \\
\text { 2005-2012 (vaccination era) }\end{array}$ & $\begin{array}{l}\text { Trend analysis of varicella-related } \\
\text { morbidity }\end{array}$ & $\begin{array}{l}\text { Significant decline of varicella incidence, } \\
\text { complications, and hospitalisations over time }\end{array}$ \\
\hline $\begin{array}{l}\text { Siedler and } \\
\text { Dettmann } \\
(2014)\end{array}$ & $\begin{array}{l}\text { Analysis of hospitalisation data; national } \\
\text { hospital discharge statistics; general } \\
\text { population in Germany; 1995-2012 (pre- } \\
\text { vaccination era and vaccination era) }\end{array}$ & $\begin{array}{l}\text { Trend analysis of varicella } \\
\text { hospitalisation incidence }\end{array}$ & $\begin{array}{l}\text { No particular trend until } 2003 \text {, hospitalisation } \\
\text { incidence peaked in } 2004 \text { (time of vaccine } \\
\text { recommendation), and decreased thereafter; } \\
\text { hospitalisation incidence per } 100,000 \text { was } \\
\text { significantly lower in the vaccination period } \\
\text { (1.86) than in the pre-vaccination period } \\
\text { (3.30) }\end{array}$ \\
\hline \multirow[t]{3}{*}{$\begin{array}{l}\text { Spackova } \\
\text { et al. (2010) }\end{array}$} & \multirow{3}{*}{$\begin{array}{l}\text { Analysis of surveillance data; sentinel data } \\
\text { collected by paediatricians and general } \\
\text { practitioners; general population in } \\
\text { Germany; April 2005-March } 2009 \\
\text { (vaccination era) }\end{array}$} & Cases of varicella and trend analysis & $\begin{array}{l}83,075 \text { cases; the total number of varicella } \\
\text { cases decreased over time with increasing } \\
\text { vaccine uptake }\end{array}$ \\
\hline & & Complications & $\begin{array}{l}\text { All: } 0,34 \% \text {; bacterial superinfection: } 0.13 \% \text {; } \\
\text { otitis media: } 0.06 \% \text {; neurological: } 0.03 \%\end{array}$ \\
\hline & & $\begin{array}{l}\text { Hospitalisation in varicella patients } \\
\text { with complications }\end{array}$ & $25 \%$ \\
\hline
\end{tabular}


Table 2 continued

\begin{tabular}{|c|c|c|c|}
\hline Publication & $\begin{array}{l}\text { Methods (study type, data source, } \\
\text { population, and time frame) }\end{array}$ & Outcome measures & Results \\
\hline \multirow[t]{6}{*}{$\begin{array}{l}\text { Streng et al. } \\
(2013)\end{array}$} & \multirow{6}{*}{$\begin{array}{l}\text { Analysis of surveillance and survey data; data } \\
\text { of the Bavarian Varicella Surveillance } \\
\text { Project (BaVariPro) based on parent surveys } \\
\text { (vaccination coverage), paediatric practice } \\
\text { surveillance, and paediatric hospital database } \\
\text { queries; children }<17 \text { years in Munich; } \\
\text { October 2006-September } 2011 \text { (vaccination } \\
\text { era) }\end{array}$} & Cases of varicella and trend analysis & $\begin{array}{l}16,054 \text { cases; the mean number of cases } \\
\text { decreased by } 67 \% \text { during the five seasons }\end{array}$ \\
\hline & & $\begin{array}{l}\text { Incidence per } 1000 \text { children (based on } \\
\text { the number of reported cases) }\end{array}$ & $\begin{array}{l}26 \text { per } 1000 \text { in the first season and } 6 \text { per } 1000 \text { in } \\
\text { the fifth season }\end{array}$ \\
\hline & & Complications in practice patients & $\begin{array}{l}0.8 \% \text { (mostly skin complications and otitis } \\
\text { media) }\end{array}$ \\
\hline & & Complications in hospitalised patients & $\begin{array}{l}\text { Central nervous system: } 22.5 \% \text {; skin: } 15.7 \% \text {; } \\
\text { lower respiratory tract: } 9 \%\end{array}$ \\
\hline & & Median length of hospital stay & 3 days \\
\hline & & $\begin{array}{l}\text { Hospitalisation incidence (cases per } \\
100,000 \text { children) and trend } \\
\text { analysis }\end{array}$ & $\begin{array}{l}8.2 \text { per } 100,000 ; \text { hospitalisation incidence } \\
\text { decreased by } 43 \% \text { between } 2005 \text { and } 2009\end{array}$ \\
\hline \multirow[t]{3}{*}{$\begin{array}{l}\text { Wagenpfeil } \\
\text { et al. (2004) }\end{array}$} & \multirow{3}{*}{$\begin{array}{l}\text { Retrospective epidemiological and resource } \\
\text { consumption study; clinical data were } \\
\text { obtained from medical files through } \\
\text { telephone interviews with physicians; } 1334 \\
\text { unvaccinated varicella patients of a } \\
\text { representative and German-wide sample of } \\
\text { paediatric and primary care practices; } 1999 \\
\text { (pre-vaccination era) }\end{array}$} & Complications & $\begin{array}{l}\text { All: } 5.7 \% \text {; bacterial superinfection: } 2.5 \% \\
\text { ( } \leq 12 \text { years), } 1.9 \% \text { ( }>12 \text { years); } \\
\text { neurological: } 0.2 \% \text { ( } \leq 12 \text { years); pneumonia } \\
\text { or bronchitis: } 1.9 \% \text { ( } \leq 12 \text { years), } 1.9 \% \\
\text { (>12 years); otitis media: } 1.1 \% \text { ( } \leq 12 \text { years) }\end{array}$ \\
\hline & & $\begin{array}{l}\text { Hospitalisation period per diagnosed } \\
\text { varicella case }\end{array}$ & 0.1 inpatient days \\
\hline & & $\begin{array}{l}\text { Work days lost per diagnosed varicella } \\
\text { case }\end{array}$ & 1.3 days \\
\hline \multirow{2}{*}{$\begin{array}{l}\text { Ziebold } \\
\text { et al. (2001) }\end{array}$} & \multirow{2}{*}{$\begin{array}{l}\text { Analysis of surveillance data; paediatric } \\
\text { hospital-based surveillance data (ESPED) } \\
\text { and clinical data collected through } \\
\text { questionnaires; hospitalised } \\
\text { children } \leq 16 \text { years; } 1997 \text { (pre-vaccination } \\
\text { era) }\end{array}$} & Hospitalised varicella cases & 119 \\
\hline & & $\begin{array}{l}\text { Complications in hospitalised } \\
\text { varicella cases }\end{array}$ & Neurological: $62.3 \%$; infectious: $35.2 \%$ \\
\hline
\end{tabular}

ASHIP Associations of Statutory Health Insurance Physicians, BaVariPro Bavarian Varicella Surveillance Project, DALY disability-adjusted life year, DRG diagnosis-related group, ESPED Erhebungseinheit für seltene pädiatrische Erkrankungen in Deutschland (German paediatric surveillance unit), WHO World Health Organization

hospitalisation of $34 \%$ in patients $\leq 20$ years (Siedler et al. 2006). Median length of hospital stay in children was 6 days (Arenz et al. 2009). Four studies provided information on measles-related deaths, which occurred rarely and only in children (see Table 2 for details). In a German substudy of the Burden of Communicable Diseases in Europe (BCoDE) project, the average loss of DALYs per case of measles was estimated to be 0.26 resulting in an average DALY loss per year of 740 (Plass et al. 2014). The average costs per measles patient and per hospitalisation were EUR 373 and 1877, respectively (Wichmann et al. 2009).

\section{Mumps}

Mean annual incidence of mumps based on claims data was estimated to be 10.3 per 100,000 people covered by statutory health insurance. Incidence was significantly higher in western federal states than in eastern federal states. A comparison between claims data and notification data indicated severe underreporting of mumps incidence in the notification surveillance system (see Table 2 for details). The main complication was orchitis affecting $6.2 \%$ of male cases. The proportion of complications in individuals $\geq 15$ years was higher than in younger patients (Takla et al. 2013). Information on the economic burden of mumps was not available.

\section{Pertussis}

In children, incidence of infections with Bordetella pertussis and Bordetella parapertussis was 4.8 and 2.8 per 1000 person-years, respectively. More than $60 \%$ of all pertussis cases in children from 3 to 8 years were caused by Bordetella pertussis (Liese et al. 2003). Incidence of pertussis requiring hospitalisation was 2.7 per 100,000 person-years in children (Juretzko et al. 2001). In adults, incidence of pertussis ranged from 160 to 169 per 100,000 inhabitants (Hellenbrand et al. 2009). The diagnosis of pertussis could be verified in $10 \%$ of the primary care patients having cough for $\geq 7$ days (Riffelmann et al. 2006). In children $<2$ years presenting with cough for $\geq 7$ days, pertussis was diagnosed in $6.6 \%$ of the cases (Stojanov et al. 2000). Pertussis-associated hospitalisation rate was 1.5 and 1.7 per 100,000 population in the western and eastern federal states, respectively (Hellenbrand et al. 2009). Most of the hospitalisations occurred in 
children $<1$ year (Juretzko et al. 2001). More than $40 \%$ of hospitalised children suffered from complications, and the mean length of hospitalisation in children varied between 8 and 14.9 days (Juretzko et al. 2001; Stojanov et al. 2000). Direct costs per case of pertussis were EUR 120 in primary care patients, and indirect costs per case were EUR 2443 in employed patients (Riffelmann et al. 2006). None of the reviewed studies focused on older adults ( $>60$ years).

\section{Varicella}

Studies analysing surveillance data from the vaccination era showed a decline of varicella incidence and hospitalisations over time and with increasing vaccine uptake (Siedler and Arndt 2010; Siedler et al. 2013b; Siedler and Dettmann 2014; Spackova et al. 2010; Streng et al. 2013). The proportion of patients with complications was higher in the pre-vaccination era $(5.7 \%)$ (Wagenpfeil et al. 2004) than in the vaccination era (0.34-0.8 \%) (Spackova et al. 2010; Streng et al. 2013). Annual incidence of varicella-related hospitalisations varied from 3.25 to 19.7 per 100,000 children depending on the data source used before routine childhood vaccination against varicella was implemented (Liese et al. 2008). About $80 \%$ of these (hospitalised) children suffered from varicella-related complications, and most frequent complications were neurological and infectious complications (Liese et al. 2008; Ziebold et al. 2001). In the pre-vaccination era, annual varicella-associated mortality in children was 0.4 per million (Grote et al. 2007), and societal costs of varicella were estimated at EUR 187.5 million per year (Banz et al. 2004). However, direct medical costs accounted for only $18 \%$ of these costs. Work days lost per diagnosed varicella case were 1.3 days (Wagenpfeil et al. 2004).

\section{Analysis of surveillance data}

The numbers of reported cases of measles, mumps, pertussis, and varicella over time are shown in Fig. 2. Nationwide mandatory notification of measles was introduced in 2001. Since then, the number of reported cases of measles varied from year to year. Mumps, pertussis, and varicella became officially notifiable diseases in Germany in 2013. Hence, the numbers of notified cases of these diseases strongly increased from that point of time. In 2014, about $70 \%$ of all reported mumps and pertussis cases occurred in adults, while most of the notified varicella cases occurred in children. For the period before 2013, notification data on mumps, pertussis, and varicella were available only for federal states in the eastern part of Germany (see dotted lines in Fig. 2).

\section{Discussion}

Our review examined available information on the epidemiology and economic burden of measles, mumps, pertussis, and varicella in Germany. In general, results differed widely by reporting year, population, and data source used. More specific key findings are discussed below.

Results of the studies investigating the measles epidemiology in Germany and latest reports on the ongoing outbreak in Berlin (RKI 2015b) clearly showed that Germany has failed in achieving the aim of eliminating measles until 2015. Some of the reviewed studies found huge regional difference in measles incidence. Most cases occurred in the context of regionally limited outbreaks, and several outbreaks were linked to transmission from Roma community members, asylum seekers, or anthroposophic communities/schools. These findings are in line with a recently published analysis of the measles epidemiology in $2014 / 2015$ by the RKI (2015b) and indicate the importance of conducting more in-depth analyses at a regional level, increasing public awareness on the benefits of immunisation, and strengthening efforts to identify and close the existing vaccination gaps. The relevance of targeting vulnerable groups such as Rome communities, anthroposophic groups, and immigrants has already been emphasised by an overview of affected groups in Europe (Muscat 2011). Comparative analyses of different data sources (notification data vs. claims data) revealed a potential underestimation of measles incidence estimates when using notification data. Hence, claims data analyses should be used more regularly to complement analyses based on surveillance systems and to provide a more comprehensive picture of the epidemiology of notifiable diseases in Germany.

Compared to measles, only very few studies have dealt with the epidemiology of mumps in Germany. However, some of the findings concerning measles also hold true for mumps such as the underreporting of incidence estimates based on surveillance data. Another similarity was found between mumps and pertussis: in 2014 , about $70 \%$ of all notified cases occurred in adults. Studies from other countries have also reported an increasing incidence of pertussis in adolescents and adults (Rothstein and Edwards 2005; McGuiness et al. 2013). Moreover, there is evidence that adults are one of the major sources of pertussis in infants (Orenstein 1999; Bisgard et al. 2004) and play a crucial role in transmitting pertussis to household members (Baptista et al. 2009). The reason for the age shift of pertussis is supposed to be the combination of less boosting by natural infections and waning of vaccine-induced immunity (Nitsch-Osuch et al. 2013). One of the reviewed studies showed that pertussis was a common cause of persistent cough in adults, which is in line with published 
data from other countries (Rothstein and Edwards 2005). In general, it is assumed that standard surveillance systems greatly underestimate the level of pertussis (Crowcroft and Pebody 2006).

Several of the included studies on varicella reported on the situation in the pre-vaccination era. Studies that are more current showed that varicella incidence and hospitalisation have decreased after the implementation of routine childhood vaccination. Similar effects have been observed after the introduction of the varicella vaccination programme in the United States (Marin et al. 2008; Baxter et al. 2014). Furthermore, the overall decline in varicella incidence and hospitalisation in the United States was not associated with a shift to older age groups (Baxter et al. 2014).

Our review revealed that information on direct and indirect costs of childhood diseases in Germany is scarce. Furthermore, not all studies that collected cost data included all relevant cost components. For example, in the study by Riffelmann et al. (2006), direct costs were calculated without considering hospitalisation cost. In contrast, the study by Banz et al. (2004) considered an additional cost category when adopting a third-party payer perspective, namely transfer payments to parents that stay at home to care for their sick children. Inclusion of this cost category can substantially increase costs from the health care payer perspective, particularly when assuming that all sick
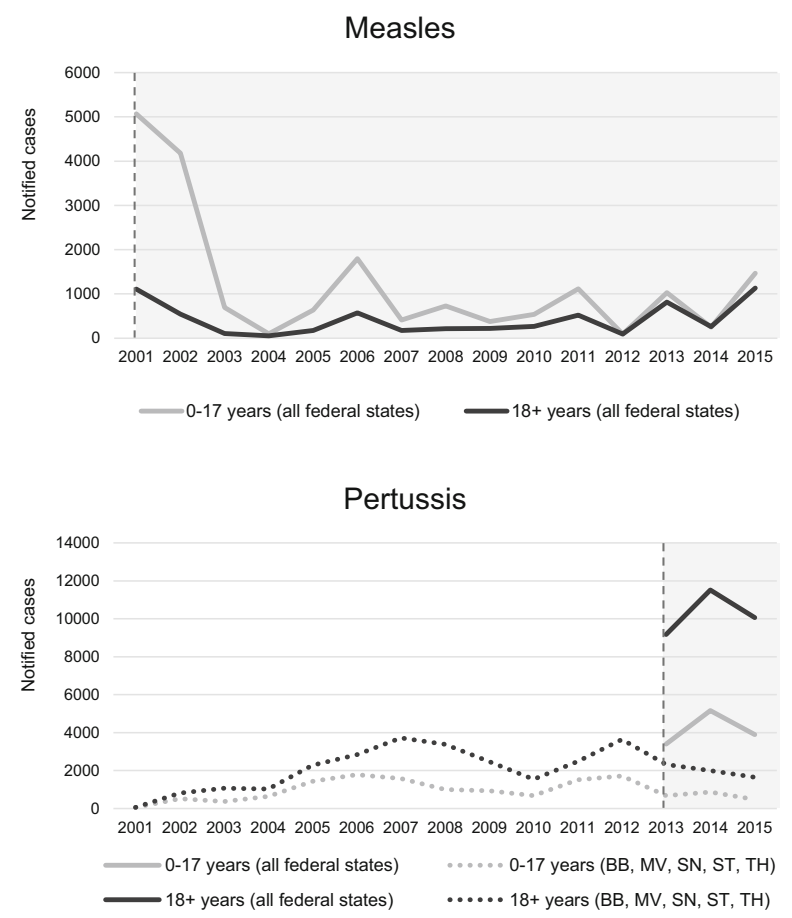

Fig. 2 Numbers of notified cases of measles, mumps, pertussis, and varicella in Germany (2001-2015) based on SurvStat@RKI 2.0. Vertical dashed lines indicate the date of nationwide implementation children cause parental absence from work. For instance, in the study by Banz et al. (2004), the mean number of parental work days lost per sick child ranged from 0.6 to 4 depending on the course of disease, and as a consequence, the reimbursed costs of parental work days lost accounted for $57 \%$ of the total third-party payer costs.

The use of different outcome measures also hampers the comparison of economic results across studies. The study by Carabin et al. (2003), which estimated the costs of measles for 11 countries, used per capita costs (approximately EUR 0.02) as economic outcome measure, whereas the study by Wichmann et al. (2009) presented results in terms of costs per measles patient (EUR 373) and costs per hospitalised patient (EUR 1877).

In summary, since only few studies have provided cost estimates so far, future research should concentrate on quantifying the economic burden of disease. A more intensified use of claims data analyses might contribute to this aim. Also, administrative data from health insurance funds might provide a good foundation to supplement surveillance data (Jones et al. 2013) and to extend existing methods of measuring underreporting of notified cases of infectious diseases (Gibbons et al. 2014). However, as current case definitions include not only laboratory-confirmed cases but also clinically diagnosed cases (RKI 2015a), notification data might also be subject to
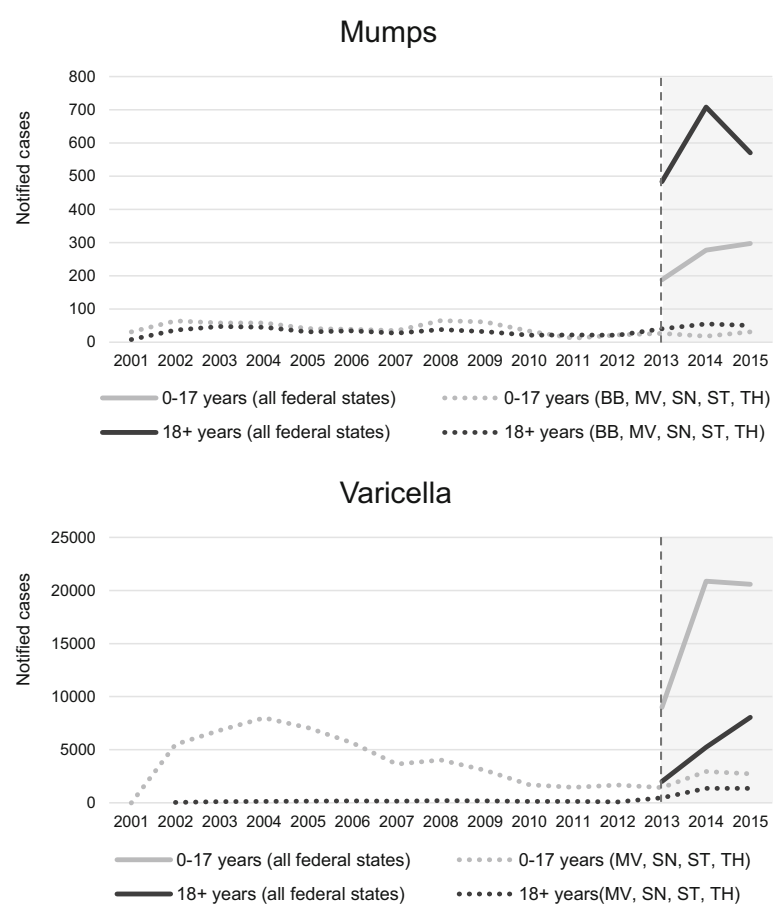

of mandatory notification. $B B$ Brandenburg, $M V$ Mecklenburg-West Pomerania, $S N$ Saxony, ST Saxony-Anhalt, $T H$ Thuringia 
overestimation. Certainly, the same is true for health insurance claims data, since the validity of the recorded diagnoses is largely unknown.

\section{Limitations}

There are several limitations of our systematic review. First, since the scope of our review was limited to studies presenting results for Germany, transferability of results to other countries is limited, too. Second, due to the high heterogeneity of the included studies, an assessment of methodological quality was not performed. Third, many of the included studies were based on surveillance data that might be subject to underreporting. Fourth, case definitions varied among studies, which might partially explain differences in results.

\section{Conclusions}

This review aimed to provide an overview of the epidemiology and economic burden of measles, mumps, pertussis, and varicella in Germany. Most of the reviewed studies presented epidemiological outcomes. Studies providing information on economic aspects except hospitalisation were scarce.

Despite the existing immunisation recommendations, results suggest that there is still considerable morbidity due to childhood diseases in Germany. However, not only children are affected. For instance, a high proportion of all pertussis cases occurs in adults. Furthermore, several studies revealed regional differences in incidence of some of the target diseases. These findings underline the need for improved vaccination and communication strategies targeting all susceptible age and risk groups on a national and local level.

Acknowledgments The authors would like to thank Roeland Van Kerckhoven (consultant for Keyrus Biopharma) for editorial assistance and public coordination on behalf of GSK Vaccines.

\section{Compliance with ethical standards}

Conflict of interest OD worked on Projects funded by the GSK group of companies, Sanofi Pasteur MSD and AstraZeneca Germany. JW worked on Projects funded by the GSK group of companies and Sanofi Pasteur MSD. CP and SB worked on Projects funded by the GSK group of companies. SW is employed by the GSK group of companies and reports personal fees from GlaxoSmithKline Biologicals SA. RW is employed by the GSK group of companies and reports shares. WG declares that he has no conflict of interest.

Ethical approval This article does not contain any studies with human participants or animals performed by any of the authors.

Funding This systematic review was fully funded by GlaxoSmithKline Biologicals SA, which also funded costs associated with the development and the publishing of the present manuscript.
Open Access This article is distributed under the terms of the Creative Commons Attribution 4.0 International License (http:// creativecommons.org/licenses/by/4.0/), which permits unrestricted use, distribution, and reproduction in any medium, provided you give appropriate credit to the original author(s) and the source, provide a link to the Creative Commons license, and indicate if changes were made.

\section{References}

Arenz S, Fischer R, Wildner M (2009) Measles outbreak in Germany: clinical presentation and outcome of children hospitalized for measles in 2006. Pediatr Infect Dis J 28:1030-1032

Banz K, Wagenpfeil S, Neiss A, Hammerschmidt T, Wutzler P (2004) The burden of varicella in Germany: potential risks and economic impact. Eur J Health Econ 5:46-53

Baptista P, Magalhães V, Rodrigues L (2009) The role of adults in household outbreaks of pertussis. Int J Infect Dis 14:e111-e114

Baxter R, Tran TN, Ray P, Lewis E, Fireman B, Black S, Shinefield HR, Coplan PM, Saddier P (2014) Impact of vaccination on the epidemiology of varicella: 1995-2009. Pediatrics 134:24-30

Bisgard KM, Pascual FB, Ehresmann KR, Miller CA, Cianfrini C, Jennings CE, Rebmann CA, Gabel J, Schauer SL, Lett SM (2004) Infant pertussis. Who was the source? Pediatr Infect Dis J 23:985-989

Carabin H, Edmunds WJ, Glydmark M, Beutels P, Lévy-Bruhl D, Salo H, Griffiths UK (2003) The cost of measles in industrialised countries. Vaccine 21:4167-4177

Centers for Disease Control \& Prevention (CDC) (1999) Ten great public health achievements United States, 1900-1999. Morb Mortal Wkly Rep 48:241-243

Crowcroft NS, Pebody RG (2006) Seminar: recent developments in pertussis. Lancet 367:1926-1936

Declich S, Carter AO (1994) Public health surveillance: historical origins, methods and evaluation. Bull World Health Organ 72:285-304

Devleesschauwer B, Havelaar AH, Maertens de Noordhout C, Haagsma JA, Praet N, Dorny N, Duchateau L, Torgerson PR, Van Oyen H, Speybroeck N (2014) Calculating disabilityadjusted life years to quantify burden of disease. Int J Public Health 59:565-569

Gibbons CL, Mangen MJ, Plass D, Havelaar AH, Brooke RJ, Kramarz P, Peterson KL, Stuurman AL, Cassini A, Fèvre EM, Kretzschmar ME, Burden of Communicable diseases in Europe consortium (2014) Measuring underreporting and under-ascertainment in infectious disease datasets: a comparison of methods. BMC Public Health 14:147

Gillesberg Lassen S, Schuster M, Stemmler M, Steinmüller A, Matysiak-Klose D, Mankertz A, Santibanez S, Wichmann O, Falkenhorst G (2014) Measles outbreak spreading from the community to an anthroposophic school, Berlin, 2011. Epidemiol Infect 142:789-796

Grote V, von Kries R, Springer W, Hammersen G, Kreth HW, Liese J (2007) Varicella-related deaths in children and adolescentsGermany 2003-2004. Acta Paediatr 97:187-192

Hegasy G, Kätzner K, Helle M, Mankertz A, Baumgarte S, Wille A, Fell G (2012) Description of measles D4-Hamburg outbreak in Hamburg, Germany, December 2008 to June 2009, which disproportionally affected a local Roma community. Euro Surveill 17. [pii]:20194

Hellenbrand W, Beier D, Jensen E, Littmann M, Meyer C, Oppermann H, Wirsing von König CH, Reiter S (2009) The epidemiology of pertussis in Germany: past and present. BMC Infect Dis 9:22 
Jones SG, Coulter S, Conner W (2013) Using administrative medical claims data to supplement state disease registry systems for reporting zoonotic infections. J Am Med Inform Assoc 20:193-198

Juretzko P, Fabian-Marx T, Haastert B, Giani G, von Kries R, Wirsing von König CH (2001) Pertussis in Germany: regional differences in management and vaccination status of hospitalized cases. Epidemiol Infect 127:63-71

Klein S, Schöneberg I, Krause G (2012) Vom Zwang zur Pockenschutzimpfung zum Nationalen Impfplan. Bundesgesundheitsblatt Gesundheitsforschung Gesundheitsschutz 55:1512-1523

Liese JG, Renner C, Stojanov S, Belohradsky BH, Munich Vaccine Study Group (2003) Clinical and epidemiological picture of B pertussis and B parapertussis infections after introduction of acellular pertussis vaccines. Arch Dis Child 88:684-687

Liese JG, Grote V, Rosenfeld E, Fischer R, Belohradsky BH, Kries RV, ESPED Varicella Study Group (2008) The burden of varicella complications before the introduction of routine varicella vaccination in Germany. Pediatr Infect Dis J 27:119-124

MacDonald PDM (2012) Methods of field epidemiology. Jones \& Bartlett Learning, Burlington

Mankertz A, Mihneva Z, Gold H, Baumgarte S, Baillot A, Helble R, Roggendorf H, Bosevska G, Nedeljkovic J, Makowa A, Hutse V, Holzmann H, Aberle SW, Cordey S, Necula G, Mentis A, Korukluoğlu G, Carr M, Brown KE, Hübschen JM, Muller CP, Mulders MN, Santibanez S (2011) Spread of measles virus D4Hamburg, Europe, 2008-2011. Emerg Infect Dis 17:1396-1401

Marin M, Meissner HC, Seward JF (2008) Varicella prevention in the United States: a review of successes and challenges. Pediatrics 122:e744-e751

McGuiness CB, Hill J, Fonseca E, Hess G, Hitchcock W, Krishnarajah G (2013) The disease burden of pertussis in adults 50 years old and older in the United States: a retrospective study. BMC Infect Dis 13:32

Mette A, Reuss AM, Feig M, Kappelmayer L, Siedler A, Eckmanns T, Poggensee G (2011) Under-reporting of measles-an evaluation based on data from North Rhine-Westphalia. Dtsch Arztebl Int 108:191-196

Moher D, Liberati A, Tetzlaff J, Altman DG (2009) Preferred reporting items for systematic reviews and meta-analyses: the PRISMA statement. David Moher and colleagues introduce PRISMA, an update of the QUOROM guidelines for reporting systematic reviews and meta-analyses. BMJ 339:332-336

Murray CJL (1994) Quantifying the burden of disease: the technical basis for disability-adjusted life years. Bull World Health Organ 72:429-445

Murray CJL, Ezzati M, Flaxman AD, Lim S, Lozano R, Michaud C, Naghavi M, Salomon JA, Shibuya K, Vos T, Wikler D, Lopez AD (2012) GBD 2010: design, definitions, and metrics. Lancet 380:2063-2066

Muscat M (2011) Who gets measles in Europe? J Infect Dis 204:353-365

Muscat M, Bang H, Wohlfahrt J, Gilsmann S, Mølbak K, Measles in Europe: An epidemiological assessment (2009) Measles in Europe: an epidemiological assessment. Lancet 373:383-389

Muscat M, Shefer A, Ben Mamou M, Spataru R, Jankovic D, Deshevoy S, Butler R, Pfeifer D (2014) The state of measles and rubella in the WHO European Region, 2013. Clin Microbiol Infect 20:12-18

Nitsch-Osuch A, Korzeniewski K, Kuchar E, Zielonka T, Życińska K, Wardyn K (2013) Epidemiological and immunological reasons for pertussis vaccination in adolescents and adults. Respir Physiol Neurobiol 187:99-103
Oleckno WA (2008) Epidemiology: concepts and methods. Waveland Press, Long Grove

Orenstein WA (1999) Pertussis in adults: epidemiology, signs, symptoms, and implications for vaccination. Clin Infect Dis 28:147-150

Otto W, Mankertz A, Santibanez S, Saygili H, Wenzel J, Jilg W, Wieland W, Borgmann S (2010) Ongoing outbreak of mumps affecting adolescents and young adults in Bavaria, Germany. Euro Surveill 15. [pii]:19748

Plass D, Mangen MJ, Kraemer A, Pinheiro P, Gilsdorf A, Krause G, Gibbons CL, Van Lier A, McDonald SA, Brooke RJ, Kramarz P, Cassini A, Kretzschmar ME (2014) The disease burden of hepatitis B, influenza, measles and salmonellosis in Germany: first results of the Burden of Communicable Diseases in Europe Study. Epidemiol Infect 142:2024-2035

Riffelmann M, Littmann M, Hülsse C, O’Brien J, Wirsing von König $\mathrm{CH}$ (2006) Pertussis: incidence, symptoms and costs. Dtsch Med Wochenschr 131:2829-2834

RKI (2014) Empfehlungen der Ständigen Impfkommission (STIKO) am Robert Koch-Institut. Epidemiol Bull 34:305-340

RKI (2015a) Falldefinitionen des Robert Koch-Instituts zur Übermittlung von Erkrankungs- oder Todesfällen und Nachweisen von Krankheitserregern, Ausgabe 2015. http://www.rki.de/DE/ Content/Infekt/IfSG/Falldefinition/falldefinition_node.html. Accessed 4 Apr 2016

RKI (2015b) Überblick über die Epidemiologie der Masern in 2014 und aktuelle Situation in 2015 in Deutschland. Epidemiol Bull 10:69-82

Roggendorf H, Santibanez S, Mankertz A, van Treeck U, Roggendorf M (2012) Two consecutive measles outbreaks with genotypes D8 and D4 in two mainly unvaccinated communities in Germany. Med Microbiol Immunol 201:349-355

Rothstein E, Edwards K (2005) Health burden of pertussis in adolescents and adults. Pediatr Infect Dis J 24:44-47

Roush SW (2011) Chapter 19: Enhancing surveillance. In: Manual for the surveillance of vaccine-preventable diseases, Centers for Disease Control and Prevention. http://www.cdc.gov/vaccines/ pubs/surv-manual/. Accessed 4 Apr 2016

Roush SW, Murphy TV (2007) Historical comparisons of morbidity and mortality for vaccine-preventable diseases in the United States. JAMA 298:2155-2163

Siedler A, Arndt U (2010) Impact of the routine varicella vaccination programme on varicella epidemiology in Germany. Euro Surveill 15. [pii]:19530

Siedler A, Dettmann M (2014) Hospitalization with varicella and shingles before and after introduction of childhood varicella vaccination in Germany. Hum Vaccin Immunother 10:3594-3600

Siedler A, Leitmeyer K (2004) Die Bedeutung von Sentinels für die Implementierung und Evaluation von Impfstrategien. Bundesgesundheitsblatt Gesundheitsforschung Gesundheitsschutz 47:1136-1143

Siedler A, Tischer A, MankertzA Santibanez S (2006) Two outbreaks of measles in Germany 2005. Euro Surveill 11:131-134

Siedler A, Gruber A, Mankertz A (2013a) Measles surveillance in Germany: from sentinel to mandatory surveillance. Bundesgesundheitsblatt Gesundheitsforschung Gesundheitsschutz 56:1321-1328

Siedler A, Hecht J, Rieck T, Tolksdorf K, Hengel H (2013b) Varicella vaccination in Germany: a provisional appraisal in the context of MMR vaccination. Bundesgesundheitsblatt Gesundheitsforschung Gesundheitsschutz 56:1313-1320

Sin MA, Zenke R, Rönckendorf R, Littmann M, Jorgensen P, Hellenbrand W (2009) Pertussis outbreak in primary and secondary schools in Ludwigslust, Germany demonstrating the role of waning immunity. Pediatr Infect Dis J 28:242-244 
Spackova M, Muehlen M, Siedler A (2010) Complications of varicella after implementation of routine childhood varicella vaccination in Germany. Pediatr Infect Dis J 29:884-886

Stojanov S, Liese J, Belohradsky B (2000) Hospitalization and complications in children under 2 years of age with Bordetella pertussis infection. Infection 28:106-110

Streng A, Grote V, Carr D, Hagemann C, Liese JG (2013) Varicella routine vaccination and the effects on varicella epidemiologyresults from the Bavarian Varicella Surveillance Project (BaVariPro), 2006-2011. BMC Infect Dis 13:303

Takla A, Wichmann O, Klinc C, Hautmann W, Rieck T, Koch J (2013) Mumps epidemiology in Germany 2007-2011. Euro Surveill 18. [pii]:20557

Takla A, Wichmann O, Rieck T, Matysiak-Klose D (2014) Measles incidence and reporting trends in Germany, 2007-2011. Bull World Health Organ 92:742-749

Tischer A, Siedler A, Rasch G (2001) Surveillance of measles in Germany. Gesundheitswesen 63:703-709

Tischer A, Siedler A, Santibanez S, Grüber A, Rasch G (2002) Are measles still a problem in Germany? Results of a nation-wide laboratory-based sentinel. Monatsschrift fur Kinderheilkunde 150:1077-1086

Voigt K, King NB (2014) Disability weights in the global burden of disease 2010 study; two steps forward, one step back? Bull World Health Organ 92:226-228
Wadl M, Siedler A, Krämer W, Haindl ME, Gebrande S, Krenn-Lanzl I, Mankertz A, Hautmann W (2011) Measles transmission from an anthroposophic community to the general population, Germany 2008. BMC Public Health 11:474

Wagenpfeil S, Neiss A, Banz K, Wutzler P (2004) Empirical data on the varicella situation in Germany for vaccination decisions. Clin Microbiol Infec 10:425-430

WHO (2010) Renewed commitment to elimination of measles and rubella and prevention of congenital rubella syndrome by 2015 and sustained support for polio-free status in the WHO European Region. (http://www.who.int/immunization/sage/3_Resolution_ EURO_RC60_eRes12.pdf). Accessed 11 June 2015

Wichmann O, Hellenbrand W, Sagebiel D, Santibanez S, Ahlemeyer G, Vogt G, Siedler A, van Treeck U (2007) Large measles outbreak at a German public school, 2006. Pediatr Infect Dis J 26:782-786

Wichmann O, Siedler A, Sagebiel D, Hellenbrand W, Santibanez S, Mankertz A, Vogt G, Uv Treeck, Krause G (2009) Further efforts needed to achieve measles elimination in Germany: results of an outbreak investigation. Bull World Health Organ $87: 108-115$

Ziebold C, von Kries R, Lang R, Weigl J, Schmitt HJ (2001) Severe complications of varicella in previously healthy children in Germany: a 1-year survey. Pediatrics 108:E79 